\title{
Integration Techniques of Ecological Restoration and Mining in Open Pit Coal Mine
}

\author{
Ziling Song ${ }^{1, a}$, Dongyang Zhao ${ }^{1, b}$,Yuxiang Zhou ${ }^{1, \mathrm{c}}$,Junfu Fan ${ }^{1, \mathrm{~d}}$, Yushi Ji ${ }^{2, \mathrm{e}}$ \\ ${ }^{1}$ Liaoning Technical University, Fuxin City, Liaoning Province, People's Republic of China,123000 \\ ${ }^{2}$ Shenyang Branch of China Coal Research Institute, Fushun City, Liaoning Province, People's \\ Republic of China, 113122 \\ asongziling-163@163.com, ${ }^{b}$ zhaodongyang1980@163.com,

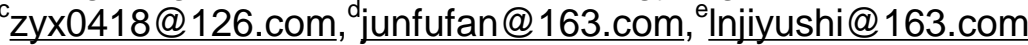

\begin{abstract}
Keywords: surface coal mine; green mining; Integrated technique; green degree
Abstract. The ecological environment problems in open pit mining and the present situation of coal mining are analyzed. The traditional open pit mining aims at pursuing economic interests, which leads to serious ecological environment problems. Open pit mining will cause the comprehensive destruction of the solid environment, water body environment, gas environment and ecological environment. Ecological restoration of opencast mine and mining Integration techniques is an effective way to solve the environmental problems of open-pit mine; Ecological restoration become as an important unit of surface mining technology, and the green mining technology system is formed; It is defined that the open-pit mining technology green system and the composition of technology units; We put forward and defined "green degree" concept and the connotation; Through evaluating the green degree index of open-pit mining, the open pit are promoted using a series of integration technologies for ecological restoration and mining, and the green mining goal is realized; The Integration techniques of open-pit mine ecological restoration and mining include two aspect of open-pit lifecycle integration, and ecological restoration progress and stripping progress.
\end{abstract}

\section{Introduction}

China has long been a major coal mining and consumption. In recent years, coal production increased rapidly. The coal yield are $3240 \mathrm{Mt}$ In 2010, 3520Mt in 2011, 3650Mt in 2012, $3680 \mathrm{Mt}$ in 2013, $3870 \mathrm{Mt}$ in 2014, $3750 \mathrm{Mt}$ in2015, there into, the open pit mining coal production reached 520 Mt, accounting for about 14\%, and increased year by year. Medium-sized opencast coal mines more than 120 , the design yield scale in the tens of millions tons of open pit coal mine nearly 30 . The new development of the construction of China's large and medium-sized opencast coal mine are mostly distributed in Inner Mongolia, Xinjiang, Shanxi and other places, the fragile ecological environment, coal open-pit mining on the ecological environment destruction is very serious, such as the destruction and occupation of land, produce smoke air pollution, destruction of groundwater balance, surface water pollution, landslide and ground subsidence geological environment disasters. The cost of its late governance is huge, technical difficulty is also great. Although, we have strengthened the ecological environment protection and protection of the mining area, however, there are still the following problems: ${ }^{[1,2,3]}$

(1) Coal mining and ecological reconstruction is not coordinated. In the design and production process of coal, "mining" and "environmental protection" is the two independent process, there is no integrated system.

(2) The model of environmental management after mining is not scientific. Open pit to focus only on the yield and economic benefit of coal mine, ignoring the protection of ecological environment, this model makes the ecological environment destruction, huge pollution lasted for a long time, with the whole process of open-pit mining, continued in open pit mine closed after. Late environmental control technology is difficult, and high cost. 
(3)The area occupied by open pit mining and the destruction of the land is enormous. Open pit, waste dump, coal storage, industrial square while occupying huge land, and caused the destruction of the ecological environment.

(4)The destruction and pollution of the solid, liquid, gas, and ecological environment caused by open pit mining. Comprehensive environmental pollution control is difficult.

It is because of the above ecological environment problems in the open pit mining, there is no treatment of coal mining and ecological protection of the coordination relationship, resulting in the ecological environment of the open pit coal mine area is deteriorating. For example, in twentieth Century 50s, the construction of the Liaoning Fuxin Mining Group Haizhou open-pit coal mine, West open pit coal mine of Fushun mining group, through the development of more than half a century, leaving a huge pit in the urban area, a huge dump occupy a lot of land. Haizhou open-pit coal mine, Fushun west open-pit mine covers an area of $8.0 \mathrm{~km}^{2}$ and $10.87 \mathrm{~km}^{2}$ respectively, Haizhou opencast coal mine have 3 dumps which occupy land area of $13 \mathrm{~km}^{2}$. The dumps vegetation coverage is low. The effect caused by the surface water and acidic heavy metal pollution on the surrounding land. The open pit slope around due to impact caused surface subsidence, cracks, a direct threat to the surrounding buildings and the safety of property.

21 Century newly developed more than 30 large open pit coal mines, such as the Shengli mining area in Xilin Gol, Baiyinhua coal mining area in Xiwuzhumuqin county of Inner Mongolia. The open pit coal mine area is located in the grassland area, its development will seriously damage the ecological environment, the sustainable development of grassland animal husbandry in China have a significant impact. Serious environmental problems caused by mining, the reason is insufficient, in addition to environmental governance investment governance effect is poor, more important is the open-pit mining and ecological restoration has not formed the integration, has not reached the green mining. he use of green mining technology integration of mining and the environment is the basic way to solve the problems of ecological environment in coal mining area, therefore, research on "mine ecological environment and mining technology integration" has important theoretical and practical value. ${ }^{[4,5,6,7]}$

\section{Analysis of the influence of open pit coal mining on ecological environment}

\section{Defects in the traditional open pit mining design theory}

In China, the design of open pit mining is mainly based on the early design theory of Russian open pit mine. The design principle is "mining technology and mining condition matching, Mining method and mining condition matching", The target of the mining scheme is: "technology is feasible; reasonable economic; safety and reliability". Under the guidance of this kind of design thought, the design of open pit mining mainly considers the feasibility of open pit mining and the maximum of economic benefit. Its design has the following obvious defects: (1)Without consideration of ecological environment restoration, (2) The passive mode of the first mining after the governance environment is formed. Which led to serious ecological environment problems, such as Open pit mine: land occupation and destruction of the large area; Mining drainage: destruction of underground water balance, mining area near the underground water level drop; Coal spontaneous combustion: produce toxic and harmful gases and smoke, a serious pollution of the atmosphere; Truck transport technology: a large number of exhaust emissions and fuel consumption; Units work: the fly ash (coal dust, rock dust), noise; Open pit mining: the destruction and pollution of solid, liquid, gas and ecological environment. ${ }^{[8,9,10,11]}$ 


\section{Type of environmental disaster caused by open pit coal mine}

The comprehensive destruction and pollution of solid, liquid, gas and ecological environment caused by open pit mining in the mining area is shown in Fig.1. ${ }^{[12,13,14,15]}$

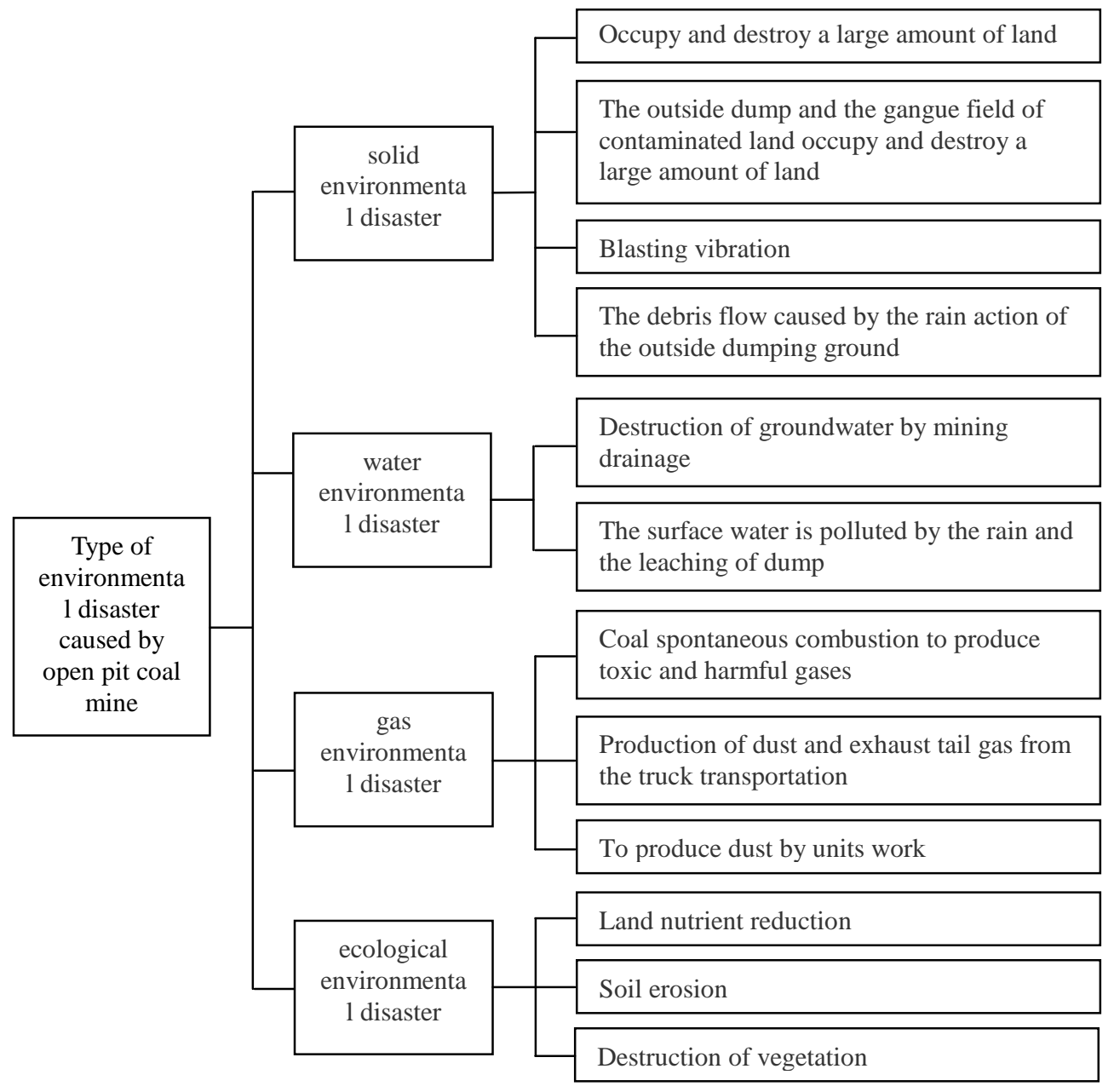

Fig. 1 types of environmental disasters in open pit mine

\section{Integration technique of ecological restoration and mining in open pit coal mine}

Using green mining technique, the formation of coal mining and ecological restoration of the integration of technique is to solve the problem of open pit coal mine ecological environment of the fundamental way. To realize the goal of green mining in open pit coal mine, the traditional model of the first mining and later stage environmental governance is needed to be changed to "control the environmental impact of coal mining from the fountainhead. ", The theoretical system of green mining in open pit mine is established, which is the main technology units of "producing preparation, loading, transportation, dumping and ecological reconstruction". The introduction of "green degree" and "green factor" conception to establish the objective function of open pit mining to achieve the goal of ecological environmental protection. Through the study of the relationship between open pit mining and solid environment, water environment, atmospheric environment and ecological environment, put forward a series of green mining techniques, such as the steep slope, steep slope mining technique, reduce the area technique of outside dump, hole by hole blasting, open pit and dump the curtain and control dust technique, green mining technology, closed pit control technique, etc., The green mining theory system of the integration of ecological environment restoration and exploitation of open pit coal mine is formed. 


\section{Concept and connotation of "green degree" in open pit coal mine}

Open pit coal mine "green degree" is a comprehensive index to express the degree of ecological environment protection in open pit coal mine.

(1) The concept and connotation of "green degree"

It is conducive to the protection of the ecological environment as the goal, whitch is a comprehensive ratio indicators about the opencast mining conditions, natural conditions and ecological environment conditions of one open-pit mine under ideal conditions. Under ideal conditions, the indexes of open pit mine, is to refer to the best index that can be achieved in China under the current level of open pit mining technology. 。 According to the type of air environment of open pit coal mine, the "green degree" of open pit coal mine is divided into: solid environment degree, water environment green degree, gas environment green degree, ecological environment green degree.

(2)The expression of "green degree" in open pit coal mine

The green degree of open pit coal mine is a relative index, which is the value of $[0,1]$, the greater the value, the better of the ecological environment protection. its mathematical model expression is:

$$
G=k_{s} G_{s}+k_{w} G_{w}+k_{g} G_{g}+k_{e} G_{e}
$$

In formula: $G$--Comprehensive green degree of open pit mine;

$G_{s^{-}}$-Green degree of solid environment;

$G_{w^{-}}$-Green degree of water environment;

$G_{g^{-}}$-Green degree of gas environment;

$G_{e^{--}}$Green degree of ecological environment;

$K_{s} 、 k_{w}, k_{g}, k_{e^{--}}$The power coefficients respectively.

$$
\begin{aligned}
G_{s} & =\sum_{i=1}^{n_{s}} w_{i} \cdot \mu\left(X_{i}\right) \\
G_{w} & =\sum_{j=1}^{n_{w}} w_{j} \cdot \mu\left(X_{j}\right) \\
G_{g} & =\sum_{k=1}^{n_{g}} w_{k} \cdot \mu\left(X_{k}\right) \\
G_{e} & =\sum_{m=1}^{n_{e}} w_{m} \cdot \mu\left(X_{m}\right)
\end{aligned}
$$

In formula: $X_{i}, X_{j}, X_{k}, X_{m^{-}}$-Influencing factors of solid environment, water environment, gas environment and ecological environment;

$\mu\left(X_{i}\right), \mu\left(X_{j}\right), \mu\left(X_{k}\right), \mu\left(X_{m}\right)$--The green factor value of the influencing factors of the solid environment, water environment, gas environment and ecological environment. Using fuzzy variable expression, the 5 specific calculation models are as follows:

$$
\begin{aligned}
& \mu\left(X_{i}\right)=\frac{X_{i}-X_{i \min }}{X_{i \max }-X_{i \min }},\left(\text { When the } X_{i}\right. \text { is a continuous variable of rise semi-trapezoid) } \\
& \mu\left(X_{i}\right)=\frac{X_{i \max }-X_{i}}{X_{i \text { max }}-X_{i \min }}, \text { (When the } X_{i} \text { is a continuous variable of decline semi-trapezoid) } \\
& \mu\left(X_{i}\right)=\frac{X_{i}}{X_{i \max }},\left(\text { When } X_{i}\right. \text { is the ratio indicator variable) } \\
& \mu\left(X_{i}\right)=\left\{P_{k} \mid X_{i}=k, P_{k} \in[0,1], k=1,2, \mathrm{~L}, N_{i}\right\}, \text { (when } X_{i} \text { is discontinuous variable) } \\
& \mu\left(X_{i}\right)=f\left(X_{i}\right), \text { (when } X_{i} \text { is nonlinear variable) }
\end{aligned}
$$

In formula: $X_{i \max }, X_{i m i n}-$ The maximum value and minimum value of influencing factors $X_{i}$ index; to build a custom function;

$f\left(X_{i}\right)$--Based on the influence factors of $X_{i}$ on the environmental impact of the mining area 


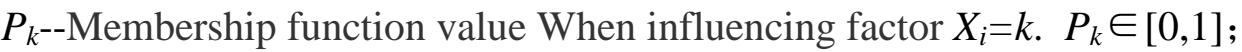

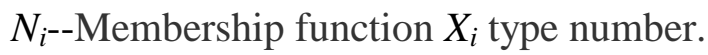

(3) The role of green degree

The green degree of open pit coal mine is a comprehensive index to identify the integration degree of the ecological environment and the exploitation of an open pit mine. It is beneficial to the ecological environment of the open pit mining area, which is the comprehensive evaluation index of natural condition, mining technology condition and level, and the effect of ecological environment protection in open pit mine. The higher the value, the better the ecological environment of the open pit mine.

The establishment of the integrated technique system of ecological restoration and exploitation

(1)The overall objective of the integration technique

To realize green mining in open pit mine, to obtain the maximum resource exploitation with the minimum environmental cost, and realize the coordinated development of the solid environment, water environment, gas environment and ecological environment of the open pit mining and mining area.

(2)The principle of integrated technique

To realize the integration of ecological restoration and mining in the open pit mine should follow the following principles: (1)Ecological restoration and exploitation of open pit mine to form a unified technological system; (2)Open pit mine ecological restoration and exploitation carry on at the same time; (3) Mining technology and economic benefit of open pit mining is subject to the protection of ecological environment.

(3)The content of integration technique

The integration technique of ecological restoration and mining in the open pit mine mainly includes the following contents: The integration technique of open pit mining technology system and work units reasonable matching; The integration technique of ecological restoration and exploitation in time and space; Production management integration.

\section{The technology system integration}

The concept and connotation of the integrated technology system of ecological restoration and mining in open pit coal mine

The integrated technological system of ecological restoration and exploitation of open pit coal is defined as "a general designation of complete mining, transportation, unloading, ecological restoration of the main work units of the equipment and operation way." Including mining, transportation, unloading, ecological restoration of the four main work units.

Ecological restoration is one of the indispensable main work units in green mining open pit coal mine, to make the work units of open pit coal mine link chain longer, the main function is to enforce the environmental protection and ecological restoration in the coal mining of the open pit mine, and to minimize the environmental damage in the open pit mining. The work unit of ecological restoration is the same as other work units, have a special operating equipment, operating mode, operating parameters, production capacity, etc., and other units must be reasonably matched.

Integrated technology system work units of ecological restoration and mining in open pit coal mine and its reasonable matching relationship

(1) The integrated technology system and its function

The integrated technology system of open pit coal mine is composed of four main work units: loading, transportation, unloading and ecological restoration. In which the "ecological restoration" is mainly the process of land restoration in open pit mine. And the other three units in the environmental monitoring and control through the green index to be controlled. The relationship between the various units, as shown in Fig.2. The role of each units are:

(1)Loading unit -- the central unit, the leading role.

(2)Transportation unit-- the key unit, the link and the link function.

(3) Unloading unit -- the key link, the guarantee role. 
(4)Ecological restoration unit-- an important unit, promote and protect role.
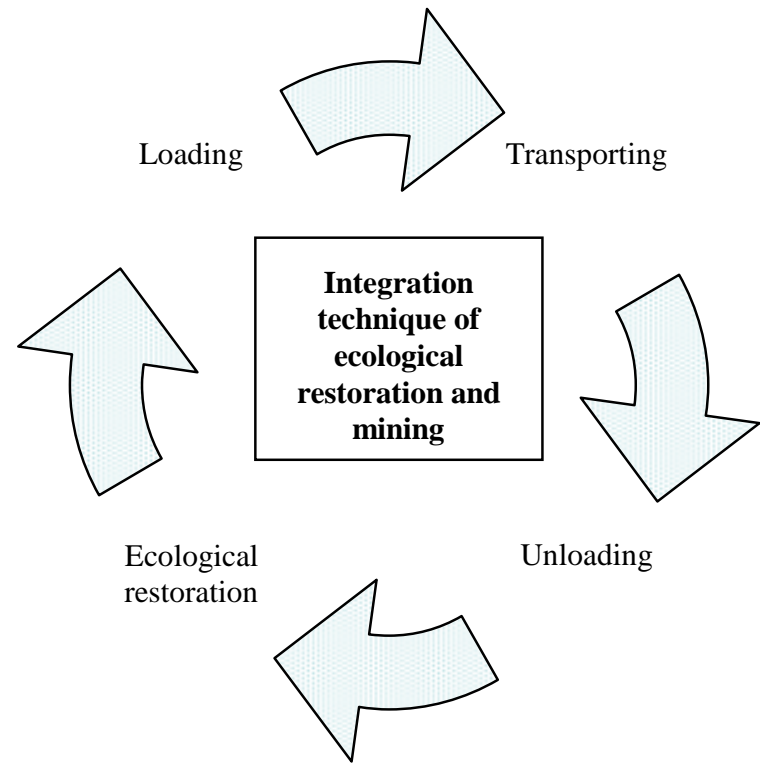

Fig.2 Relationship between the main work units of the integrated process system in the open pit coal mine

(2)The reasonable matching relationship between the work units

All work units of the open pit coal mine should match the equipment type, production capacity, equipment quantity, production organization management.

\section{(1)Equipment type matching of work units}

The choice of the type of ecological restoration equipment should be matched with the type of loading, transportation and dumping equipment. Mainly it match with dumping equipment type. Equipment matching include that one is the equipment type to be consistent, as far as possible to purchase ecological restoration equipment of the same type of mining; Two is the equipment specifications should be consistent, large-scale mining and transportation equipment is equipped with large-scale ecological restoration equipment.

\section{(2)Equipment production capacity matching of work units}

In order to give full play to the operational efficiency of each work unit, reduce the impact of each unit, the production capacity of each unit should be satisfied: the follow-up unit production capacity is not less than the previous part of the production capacity of the principle. That is:

$$
\begin{gathered}
Q_{P} \geq Q_{Y} \geq Q_{W} \\
\text { or }: Q_{P}=K_{Y} Q_{Y}=K_{W} Q_{W}, \quad\left(1 \leq K_{Y} \leq K_{W}\right)
\end{gathered}
$$

The production capacity of the ecological restoration unit and the discharging unit should be satisfied: the advancing speed of the ecological restoration work should be no less than the advancing speed of the dumping operation. In terms of the inner dumping ground, the advancing speed of the dumping is equal to that of the mining field:

$$
\begin{aligned}
& V_{T} \geq V_{P}=V_{H}, \quad(\mathrm{~m} / \mathrm{a}) \\
& V_{T}=\frac{Q_{t}}{H_{T} W_{T}}, \quad(\mathrm{~m} / \mathrm{a})
\end{aligned}
$$

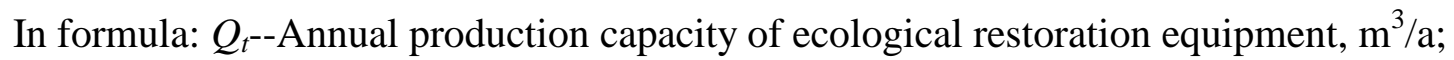

$H_{T^{-}}$-The average thickness of the fill or excavation depth (fill is positive, excavation is negative), $\mathrm{m}$;

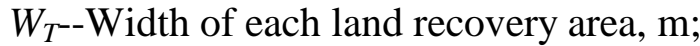

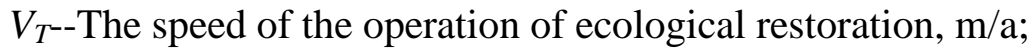


$V_{P^{-}}$The advancing speed of soil discharging operation, $\mathrm{m} / \mathrm{a}$;

$V_{H^{-}}$Open pit stripping work to help the level of advancing speed, $\mathrm{m} / \mathrm{a}$ 。

The total production capacity of ecological restoration is satisfied:

$$
Q_{T}=N_{T} Q_{t} \geq N_{T} V_{P} H_{T} W_{T}, \quad\left(\mathrm{~m}^{3} / \mathrm{a}\right)
$$

In formula: $Q_{T}, Q_{P}, Q_{Y}, Q_{W^{-}}$-Total productive capacity of ecological restoration, soil discharging, transportation and mining equipment, $\mathrm{m}^{3} / \mathrm{a}$;

$N_{T^{-}-\text {Number of land restoration operations; }}$

$K_{1}, K_{2}, K_{3}$--The ability coefficient of each unit, its value is not less than 1 .

\section{(3) The equipment number matching of work units}

The matching relationship between the number of equipments in the loading and transportation and unloading are reflected by the reasonable truck shovel ratio, the reasonable number of the unloading of dump, or the reasonable number of the dump line. The matching relationship between ecological restoration and dumping unit is mainly discussed in this part, the quantity of the equipment of the reasonable ecological restoration should be matched with the quantity of the dumping equipment. In order to ensure the coordination between the two operations, as far as possible to reduce the impact of each other, the number of equipment should be satisfied:

$$
N_{T}=K_{0} F_{z} \frac{H_{T}}{Q_{\mathrm{t}}}, \quad \text { (Set s ) }
$$

In formula: Fz--Total area of land restoration for a year, $\mathrm{m}^{2} / \mathrm{a}$;

$N_{T^{--}}$Number of ecological restoration equipment (i.e. land restoration work surfaces),Sets;

$K_{0^{--}}$The matching coefficient of ecological recovery equipment, more than or equal 1.

\section{(3) Classification of integrated technology systems}

The integrated technological system of ecological restoration and mining in the open pit is divided into the following types according to the type of equipment, operation characteristics and ecological restoration:

(1)Discontinuous mining technology + engineering repair technology

(2)Discontinuous mining technology + plant repair technology

(3)Discontinuous mining technology + microorganism repair technology

(4)Discontinuous mining technology + comprehensive repair technology(engineering, plant, microorganism)

(5)Continuous mining technology + engineering repair technology

(6) Continuous mining technology + plant repair technology

(7) Continuous mining technology + microorganism repair technology

(8)Continuous mining technology + comprehensive repair technology(engineering, plant, microorganism)

(9) Semi-continuous mining technology + engineering repair technology

(10)continuous mining technology + plant repair technology

(11) Semi-continuous mining technology + microorganism repair technology

(12) Semi-continuous mining technology + comprehensive repair technology(engineering, plant, microorganism)

(4) The type of equipment in ecological restoration

(1)According to the ecological restoration, there are several types of equipment types

Engineering repair equipment: bulldozers, forklifts, tractor, backhoe, dragline, truck, etc.;

Microbial repair equipment: biological reactor, etc.;

Plants repair equipment: bulldozers, forklifts, tractor, backhoe, dragline; truck, water tankers, irrigation equipment etc.. 

mainly

(2)According to the different types of repair environment, the required equipment types are

Solid environment - dump and open pit land repair equipment: bulldozers, forklifts, tractor, backhoe, small excavators, draglines; truck etc.;

Water environment - the equipment for the restoration of groundwater and surface water bodies: sewage treatment equipment, groundwater pumping equipment, etc.;

Gas environment - the atmospheric environment of the mining area repair equipment: watering car, dust removal equipment, fire fighting equipment, etc..

\section{Integration of ecological restoration and mining in time and space}

The integration of the ecological restoration and mining of the open pit mine includes two aspects: The whole process integration of life cycle in the open pit mine, The integration of the ecological restoration progress and the process of stripping and mining in the time and space

\section{The whole process integration of life cycle in the open pit mine}

The whole process integration of life cycle in the open pit mine is defined that the environmental protection and ecological restoration of open pit mine is in the whole process of exploration, planning, design, infrastructure, mining and production, closed pit and so on. The main tasks and contents of environmental protection and ecological restoration are different in every stage of life cycle of open pit mine.

(1) The exploration stage of open pit mine

In the exploration stage of the open pit mine, the environmental protection and ecological restoration work mainly includes: Investigation and monitoring of the basic situation of the original ecological environment in the exploration area, Need to investigate and monitor the indicators of the ecological environment, as shown in Table 1, to provide the mining area ecological environment background value.

Table 1 indicators of ecological environment in mining area

\begin{tabular}{|c|c|c|c|c|}
\hline $\begin{array}{c}\text { Serial } \\
\text { number }\end{array}$ & type & Main index & Investigation method & $\begin{array}{l}\text { Storage } \\
\text { mode }\end{array}$ \\
\hline \multirow[t]{3}{*}{1} & \multirow[t]{3}{*}{$\begin{array}{l}\text { Solid } \\
\text { environmental } \\
\text { index }\end{array}$} & Topographic features & Drawing Topographic Map & $\begin{array}{l}\text { Digital } \\
\text { graphic } \\
\text { database }\end{array}$ \\
\hline & & Present situation of land use & $\begin{array}{l}\text { According to the land use situation, } \\
\text { drawing the classification map of land use } \\
\text { status }\end{array}$ & $\begin{array}{l}\text { Digital } \\
\text { graphic } \\
\text { database }\end{array}$ \\
\hline & & Land pollution index & $\begin{array}{l}\text { Sampling according to land use type, } \\
\text { measuring the main pollutant index }\end{array}$ & Database \\
\hline \multirow[t]{7}{*}{2} & \multirow[t]{7}{*}{$\begin{array}{l}\text { Water } \\
\text { environmental } \\
\text { index }\end{array}$} & $\begin{array}{l}\text { Distribution of rivers, lakes and } \\
\text { reservoirs in mining area }\end{array}$ & River distribution map & $\begin{array}{l}\text { Digital } \\
\text { graphic } \\
\text { database }\end{array}$ \\
\hline & & $\begin{array}{l}\text { River flow rate, flow rate, lake and } \\
\text { reservoir water storage }\end{array}$ & Determination & Database \\
\hline & & $\begin{array}{l}\text { Water quality index of river water, } \\
\text { lake and reservoir }\end{array}$ & Sampling and measurement & Database \\
\hline & & Groundwater level & Geological drilling & $\begin{array}{l}\text { Digital } \\
\text { graphic } \\
\text { database }\end{array}$ \\
\hline & & Groundwater quality index & Drilling and sampling & Database \\
\hline & & $\begin{array}{l}\text { The groundwater inflow coefficient, } \\
\text { water inflow }\end{array}$ & Geological drilling & Database \\
\hline & & $\begin{array}{l}\text { Contact of groundwater and } \\
\text { waterpower }\end{array}$ & Geological drilling & Database \\
\hline \multirow[t]{2}{*}{3} & \multirow[t]{2}{*}{$\begin{array}{l}\text { Gas } \\
\text { environmental } \\
\text { index }\end{array}$} & $\begin{array}{l}\text { Atmospheric quality index of mining } \\
\text { area: API index, main harmful } \\
\text { substance } \mathrm{SO}_{2}, \text { Nox,PM10,PM2.5 }\end{array}$ & Monitor & Database \\
\hline & & $\begin{array}{l}\text { Toxic and harmful gas content in } \\
\text { coal seam }\end{array}$ & Sampling and measurement & Database \\
\hline 4 & $\begin{array}{l}\text { ecology } \\
\text { environmental } \\
\text { index }\end{array}$ & $\begin{array}{l}\text { Vegetation distribution map of } \\
\text { mining area }\end{array}$ & Draw the distribution map of vegetation & $\begin{array}{l}\text { Digital } \\
\text { graphic } \\
\text { database }\end{array}$ \\
\hline
\end{tabular}




\begin{tabular}{|c|c|c|c|c|}
\hline & & Plant diversity index & Investigation of plant diversity & Database \\
\hline & & Biological diversity index & Biodiversity survey & Database \\
\hline & & Soil nutrient index & Sampling and measurement & Database \\
\hline 5 & $\begin{array}{l}\text { Other } \\
\text { environmental } \\
\text { index }\end{array}$ & Other index & Determination and investigation & Database \\
\hline
\end{tabular}

(2) The planning and design stages

Open pit mine planning and design stage, according to the principles of ecological environment protection and exploitation at the same time planning and design, mainly to carry out the following work: (1)Comprehensive evaluation of ecological environment in mining area; (2)Prediction and evaluation of the impact of open pit mining on ecological environment; (3) According to the requirement of the ecological environment protection and the standard of the standard, a series of green mining technology is adopted in the planning and design of the open pit mine, Such as the rational exploitation of scale, green mining technology, steep slope mining technology, etc..

(3) The infrastructure stage

The infrastructure stage of the open pit mine is the initial stage of the construction of various projects in the open pit mine. Because of the more construction team, construction equipment diverse, management level difference, The infrastructure stage is a more serious damage to the ecological environment of the stage.

Therefore, strengthening the ecological environmental protection is one of the key work of this stage. The protection of the ecological environment should be included in the contract fo Party A (the owner) and Party B (the construction side), as the key assessment indicators. In real time, requires the construction side to monitor the ecological environment indicators listed in Table 1, to form a database of ecological environment index.

(4) Mining production stage

Open pit mining production stage is from the completion of the transfer of production to open pit closed longer production process, the duration up to several decades, Production stage is the largest and longest period of the ecological environment of the mining area in the open pit mine. The following work is mainly carried out on the ecological environment protection: (1) Real time monitoring of the ecological environment indicators in the mining area (generally not less than 2 times per year), to establish a dynamic database of eco environmental indicators of open pit mine; (2) Comprehensive evaluation of ecological environment every year; (3)Take a series of green mining techniqure, such as rational exploitation scale, green mining technology, steep slope mining techniqure, land restoration, mining field occupation of land dynamic management, etc..

(5) The stage of closed pit

After the open pit mining closed pit, in order to reduce the influence of open-pit mine on the ecological environment, the need for open pit abandoned mine management. The governance method is divided into: (1)The rational use of mines, such as construction of mine parks, greening, water storage pit reclamation; (2) Pit backfill, abandoned open pit land reclamation by the adjacent producing open-pit mine overburden backfilling.

The integration of the ecological restoration progress and the process of stripping and mining in the time and space

Land reclamation and ecological restoration is an indispensable unit in the open pit mine, The progress of the work schedule of ecological restoration and the progress of the stripping and mining of open pit mines should match in the time and space.

(1) The land restoration operation procedure of the dump

The land restoration in open pit mine mainly includes the land restoration of the outside and land restoration of the inner dump. Because the shape of the inner and outer dumps and the way of dumping work are different, the method of land restoration is different. First, the land restoration area is divided into different working areas, and each working area is configured with a set of ecological rehabilitation equipment, each working area is called ecological restoration work face. The ecological restoration work surface is defined as a place for the operation of a certain ecological rehabilitation 
equipment. When the equipment is in the ecological restoration, it is divided into a sequence of operation belts, This operation belt is called land smooth strip, and the width of the operation belt depends on the equipment operating parameters. According to the relationship between the belt and the dumping line, the dividing way of the land leveling belt is divided into: parallel division and vertical division. Parallel division mode is parallel to the dumping bench line; Vertical division mode is the vertical of the dumping bench line, as shown in figure 3. According to the location of land restoration, it divided into: bench berm repair and bench slope repair.

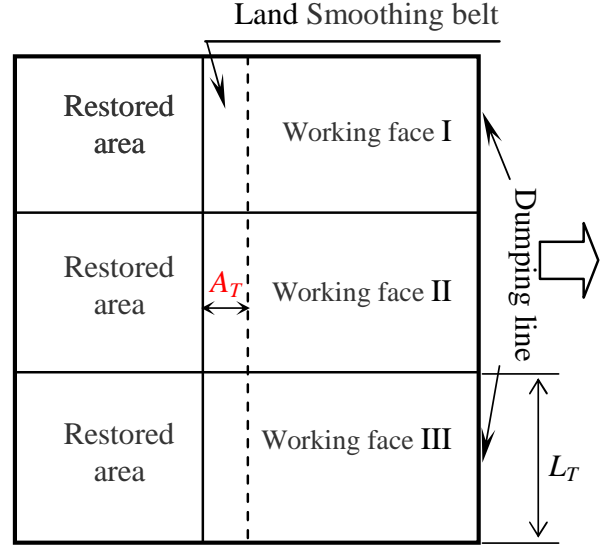

(a) parallel division of land leveling belt

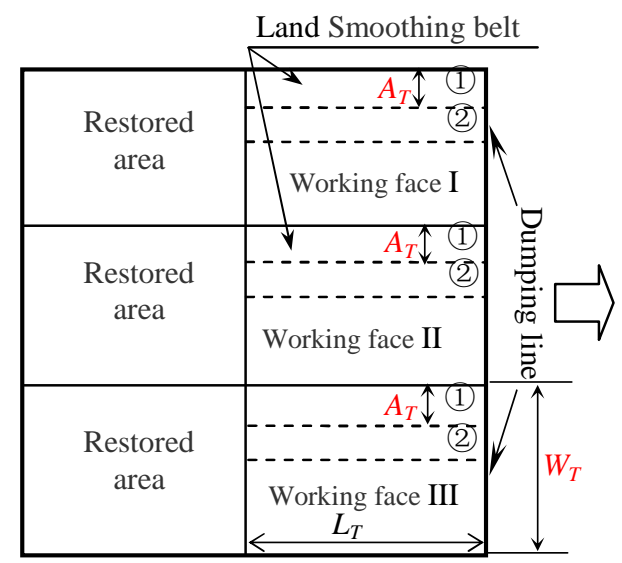

(b) vertical division of land leveling belt

(1),(2)--The order of land leveling operation

\section{Fig. 3 Schematic diagram of land recovery operations}

(2) The land restoration work satisfies following as the relation in space and time

(1)Land restoration work line length $L_{T}$

a. When parallel division of land leveling belts

$$
L_{T}=\frac{L_{p}}{n}, \quad \mathrm{~m}
$$

In formula: $L_{p^{--}}$Dumping line length of open pit mine, $\mathrm{m}$

$n$--The number of land restoration work area divided along the dumping line, $\mathrm{m}$

b. When vertical division of land leveling belts

Generally refer to the width of each land recovery region, not more than 2 times the width of the region, not less than 0.5 times the area width. That is:

$$
0.5 W_{T} \leq L_{T} \leq 2 W_{T}
$$

In formula: $W_{T^{--}}$Width of each land recovery area, $\mathrm{m}$

(2)The average thickness of the fill or excavation depth $H_{T}$

Depending on the dump bench berm roughness, and thickness of covering nutritional needs.

(3)Land restoration level follow up speed $V_{T}$

$$
V_{T}=\frac{Q_{T}}{H_{T} W_{T}}, \mathrm{~m} / \mathrm{a}
$$

In formula: $V_{T^{--}}$Its value is generally equal to the level speed of dumping bench line

$$
Q_{T^{--}} \text {Annual production capacity of a set ecological restoration equipment, } \mathrm{m}^{3} / \mathrm{a}(\mathrm{Set}) \text { 。 }
$$

\section{Production management integration}

The integration of ecological restoration and mining management in open pit mine mainly includes the following aspects:

(1)The ecological restoration link into the open pit mining technology system, unified management, unified planning, unified scheduling, unified dispatching, unified construction acceptance, unified assessment. 
(2)Establishing a special ecological restoration sector in open pit mine, and the sector is in the same position with mining, transportation, mining and other production sectors;

(3)Carrying out the dynamic management mechanism of the occupied land in the open pit mine, That is, in a certain period of time (such as 3 years to 5 years) of the open pit to the community to submit a number of land resumption land, social approval to the same number of open pit land acquisition targets. Meet the following relationships:

$$
F_{z h}=F_{h}
$$

In formula: $F_{h^{--}}$The area of land restoration in a certain period of time in dump (inside dump, outside dump) of surface mine, ha;

$F_{z} h^{-}$-The required land acquisition area in a certain period of time used produce surface mine production, ha.

\section{Conclusion}

(1)The traditional open pit mining aims at pursuing economic benefits, which inevitably leads to serious ecological environment problems. Open pit mining will cause the Comprehensive damage of the solid environment, water environment, gas environment and ecological environment.

(2)The integration of ecological restoration and mining is an effective way to solve the ecological environment problem of open pit mine;

(3)The ecological restoration is an important unit of the open pit mining technology system, composing green mining technology system;

(4)The concept and connotation of "green degree" is proposed and defined, Through the evaluation of green degree index, we can make the open pit mine adopt a series of ecological restoration and mining integration technology, to realize green mining target;

(5)The integration of the ecological restoration and mining of the open pit mine includes two aspects: The whole process integration of life cycle in the open pit mine, The integration of the ecological restoration progress and the process of stripping and mining in the time and space.

\section{Acknowledgements}

This work was financially supported by (1) The National Natural Science Fund (coal joint fund) key project (Project No. U1361211): "The green mining theory and application of large open coal mine. " (2) National Natural Science Foundation Project (Project No. 51474119):"The integration technique of mine ecological environment restoration and mining based on green degree."

\section{References}

[1]Qian Minggao. Green mining concept and the technical system of [J]. coal science and technology,2003(4):1-3(in Chinese)

[2]Tu Shihao, Chen Yixian. Discussion on green mining technology to protect the ecological environment of mining area $[\mathrm{J}]$. energy environmental protection, 2003, 17 (4): 10-13(in Chinese)

[3]Liu Jinping, Zhang Youdi, Yang Huijun. The value of mineral resources in green mining [J]. Journal of China University of Mining and Technology, 2004, 33 (2): 233-235(in Chinese)

[4]Dong Jie, Long Ruyin. Green coal mining technology innovation system model discussion[J]. Economist magazine, 2004 (11):51-52(in Chinese)

[5]Zhou Pingchuan, Wang Jiujin. Research on fiscal and taxation policies for sustainable development of coal industry [J]. tax research, 2005 (5): 50-52(in Chinese)

[6]Wang Jianguo. Rational exploitation of coal resources in China and modern open pit mining technology [J]. mining technology, 2006 (03):59-62(in Chinese) 
[7Miao Xiexing, Qian Minggao. Status quo and Prospect of research on green mining of coal resources China [J]. Journal of Mining \& Safety Engineering, 2009, 26 (1): 1-14(in Chinese)

[8]Jo Ning. Analysis of green mining technology in modern open pit coal mine [J]. science and technology innovation and application, 2012 (20):42-42(in Chinese)

[9]Li Shunyun, Dong Chang. Green mining of coal mine based on computer technology[J]. Coal technology, 2012 (05):66-68(in Chinese)

[10]Liu Yu Bo, Zhao Baijun, Liu Yibo. The method and principle of coal green mining technology [J]. Shanxi coking coal science and technology, 2012 (7):41-45(in Chinese)

[11]Zhang Jinsuo, Qi Qi, Zhang Wei, et al. Review of research on the safety and efficiency of coal resources in China [J]. resources and industry, 2013, 15 (1):1-6(in Chinese)

[12]Yang Junzhe, Chen Sushe, Wang Yi, et al. Green mining technology in Shendong mining area [J]. coal science and technology, 2013.41 (9):34-39(in Chinese)

[13] Xie Heping,Wang Jinhua,Jiang Pengfei, ect. New Concepts and Technology Evolutions in Scientific Coal Mining[J]. Engineering Sciences, 2015(09):36-41(in Chinese)

[14]Gu Dazhao;Zhang Yong;Cao Zhiguo. Technical progress of water resource protection and utilization by coal mining in China[J]. Coal Science and Technology, 2016(01):1-7(in Chinese)

[15]HAN Yichao,XIANG Di,LIU Yu,ect. Research on green mining theoretical system in open-pit coal mine[J].,Opencast Mining Technology,2016(01):81-82+83(in Chinese) 